\title{
防炎加エについて (II)
}

\section{4. 防炎理論之防炎加工剤の具備条件}

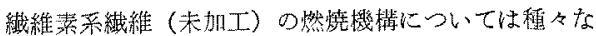

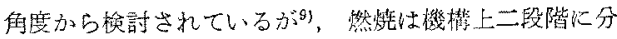
けられるといら説が確立されている。すなかち第一段階 として瀻維菜系㵶雅が $300^{\circ} \mathrm{C}$ 以上の火㷋にさらされる

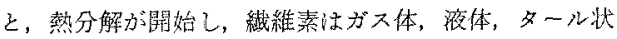
物貿，固体に分解し，可燃性ガス体は燃烧を始め，揮発 性液体㧍よびタール状物貿はさらに可然性のガス体を発

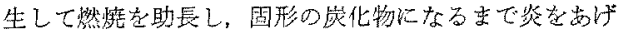

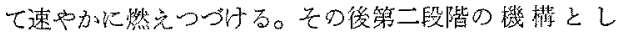
て，固形炭化物残㴰中の有機物が余じえとなって燃光，

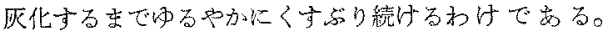
Heuser ${ }^{609}$ によると瀻維素の第一段階然暁過程中心発生 するガス体として酢酸，メチルエチルタトン，机么 アルデヒド，みタンなどでまたタール状物質は各種の

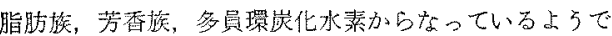
ある。

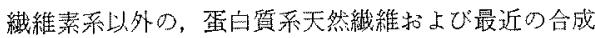

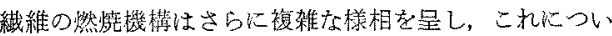

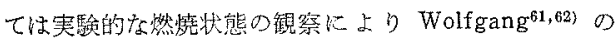
有叠義な表などが報ぜられている。

さてかかる然焼過程から導き出された瀻維の防筷加工 の理論としては，次の四つの理論が举げられている。す

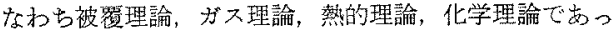
て，它の各々について詳述すると次のごとくである。

\section{（1）被覆理論 (Coating Theories)}

Gay-Lussac ${ }^{(1)}$ は，炎によって容易に溶融する塩類を

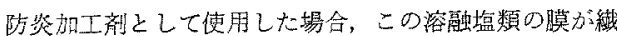
維表面贲被覆し，然燥を助長するところの空気中の酸素 の供給を遮断し，防㷋加工を発揮するといら説をたてて いる。この説は現今でもホウ耖ホウ酸の混合物の徣れた

A Review of the Flame-Proofing for Textiles. KOICHI FUKUDA

Nihon Senshoku Co., Ltd. Chuo-ku, Tokyo, Japan 日本染色株式会社 取締役 研究室長
福田耕一

防悐性の裹付けとして支持している人もある。

\section{(2) カス理論 (Gas Theories)}

㵶維素の熱分解生成物で岁る可燃性ガス体を，防资斉 の熱分解によって発生する不然性方不体にて程积し，可 燃性ガス体の燃焼を防ぐ理論で岕る。この理諭は炭酸り 一ダ，炭睃アンモン，八ロゲン化アソモン，リン酸塩， 硫酸㨫，サルフォメイト，塩化垔鉛，塩化マグネシウ ム，塩化カルシウムなどの防然剂としての働き説明す ることができるが，防炎として優れている酸化チタンと 酸化アンチモンの混合物の働きなどは説明することがで

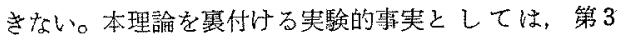

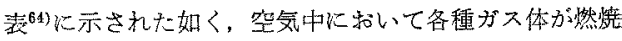
しうる涨度限界 (limits of flammability) と，そのガス 体が云の限界内に尔いて不然化されるたるの，不然性ガ ス体による最少の希秎割合があるということを知らなけ ればならない。

\section{（3）熱的理論 (Thermal Theories)}

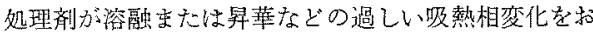
こす場合，火炎などの熱エネルギ一に不尽をきたしてし まうという説である。

(4) 化学的理諭 (Chemical Theories)

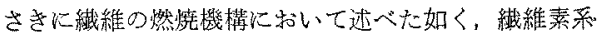
㵶維は高温で熱分解をおこし，可燃性ガ入体や揮発性タ 第 3 表 ${ }^{64)}$ 不然ガス体に上る消炎效果

\begin{tabular}{|c|c|c|c|c|c|}
\hline \multirow[t]{2}{*}{ Gas } & \multirow[t]{2}{*}{\begin{tabular}{|c|} 
Flammable \\
limits in \\
Air. \% by \\
Volume
\end{tabular}} & \multicolumn{4}{|c|}{$\begin{array}{l}\text { Minmum \% of Diluent } \\
\text { Required to Make Mix- } \\
\text { ture Nonflammable in } \\
\text { All Proportions }\end{array}$} \\
\hline & & $\begin{array}{l}\mathrm{H}_{2} \mathrm{O} \\
\mathrm{Va} \text { - } \\
\text { pour }\end{array}$ & $\mathrm{CO}_{2}$ & $\stackrel{\mathrm{CH}_{3}}{\mathrm{Br}}$ & $\mathrm{CCl}_{4}$ \\
\hline Carbon Monoxide & $12.5 \sim 77.5$ & 54 & 52 & 6.2 & 2.0 \\
\hline Methane & $5.3 \sim 16.0$ & 29 & 24 & 4.7 & 12.5 \\
\hline Ethane & 3. $0 \sim 12.5$ & - & 33 & - & - \\
\hline Ethylene & $3.1 \sim 32.0$ & - & 40 & 11.7 & - \\
\hline Benzene & $1.4 \sim 7.1$ & 35 & 31 & 7.8 & - \\
\hline Acetoaldehyde & $4.1 \sim 55.0$ & - & 79 & - & - \\
\hline Acetone & $3.0 \sim 11.0$ & - & - & - & - \\
\hline
\end{tabular}


一ル状物質なぞを生成して然㜔するが，これら易然性の ガスやタールを発生する不均一な反応を経過せす，緇維 素がすぐさま終局の炭素と水に分解する上うな理想的な 反応を想定すると，次の式の如く多䇺の水分の発生をと るならことになる。

$$
\left(\mathrm{C}_{5} \mathrm{H}_{10} \mathrm{O}_{5}\right)_{n} \longrightarrow 6 n \mathrm{C}+5 n \mathrm{H}_{2} \mathrm{O}
$$

したがって，化学的に強力な脱水作用索㗢く化合物が， 熱分解生成物として形成されるような物質を，防炎郕と して使用すれば，易然性グスの発生反坑山和こらず，上 の終局反応が促進され，防炎性が発匴されることにな る。このよらな考え力からたてられた説が化学的理諭で ある。

厦れた大部分の防资剂は，加熱状態にお゙いて瀻維の分 解を高める傾向が強い。すなわり，強酸，強塩基，金属 酸化物枋よび一般的な酸化剂の多くのものは，瀻維の分

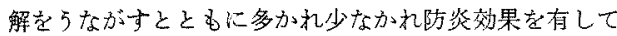

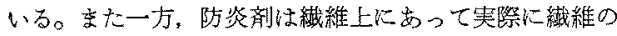
脱水反応を促するのでする。Leatherman 等 ${ }^{65)}$ やChu-

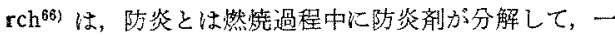
般的な酼酸，リン酸のよ5な強力な脱水触媒を生成し， 速やかな脱水反応荐起する現象であるという説を提起 している。すなわち，この場合一般的に炭酸ガスと水を 発生する繊維の然㜔反心は，前式のごく炭素と多量の水 を発生する反灾となっているわけである。

この化学的理論を普趈登展させた最近の研究や理論に いて詳述する前に，防炎效果に上って终が消光九後の も克さしの古ぶり，すなわち余じん（glow）の防止につ いての理諭について次以述へる。

\section{防じル理諭67)}

余じん燃焼は分舴残査である炭素之空気中の酸㨞との 反底で，次の二つの反応が考えられる。

(1) $\mathrm{C}+1 / 2 \mathrm{O}_{2} \longrightarrow \mathrm{CO}+26.4 \mathrm{kcal} / \mathrm{mol}$

(2) $\mathrm{C}+\mathrm{O}_{2} \longrightarrow \mathrm{CO}_{2}+94.4 \mathrm{kcal} / \mathrm{mol}$

普通消えずに余じん現象が続くのは(2)式の民㐫が進 行するのであって（1 ）式の反応では発熱量が少なすぎ て，自からの反広維持することができないしたが。 て(2)式の反応を战こさずに（1）式の反応を促進する ような薬剤が有効とされている。すなわち第 4 表のごと く，この作用の焉るリン酸アンモン処理布の余じんから 発生する $\mathrm{CO}_{2}$ と $\mathrm{CO}$ の比を測定せる例からみてもわかる ことく，末処理布にくらべて明らかに CO の量が多く

(1)の反応がらながされていることがわかる。

このよらな作用の岕る物澌としては他に，橉酸，硼 酸，翗酸りーダなどが有效であり，防炎作用化有效な矹 砂，黄化アルミ，タングステン酸ソーダ，酸化アンチモ ソなどは防しん效果がなく，むのによっては却って余じ
第 4 表 岸化物の余しんから発生する $\mathrm{CO}$ 上 $\mathrm{CO}_{2}$ の割合

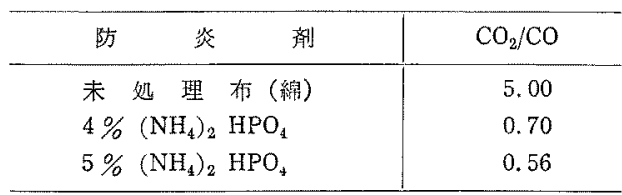

九を促焦することる刿る。

次化, 前述の化学的理諭を普延せる鼠近の研究，理論 について紹介したいと思う。

未㚾理䏡よび各種防炎㚾理瀻維素の蓺分解の究明につ いて, 荍重量分析 (Thermogravimetric Analyzer) を 手段としての破究は，1954年頃米国マサチューセッツ 州テテイックに京る米軍の研究所 Quartermaster Research and Development Command の研究がありこれはプリンストンKあるTextile Research Institute $D$ I. M. Gottlieb $\left.{ }^{69}\right)$ 品 1955 年の Tex. Research Journal 誌沈紹介している。この熱重量分析 と，示差熱分析 (Differential Thermal Analyzer) t つかっての.ニューオリンズに和けるSouthern Regional Research Lab. の-派の研究 ${ }^{70)} \not ゚$ 昨年 1966 年の Journal of Applied Polymer Science 7 月号化発表さ れている。この研究は明らかに前述の化学的理諭を裹ら けて扣り，爇重量分析により第 1 图に見られる如く，防

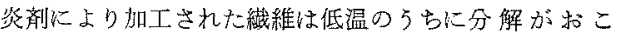
り, 発火点になる前に可然性ガス安発生し, 多くの残渣 をのこしてしま5ことがわかるわけである。

この化学的理論は他の理諭に叔いて解明し得なかった

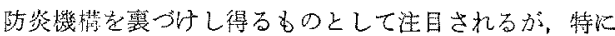
ニューネリンズに括ける学者達7月,72)が，防炎剂の究明に つさ，纎維の速中かな脱水反応区対乙，螌媒的に作用寸

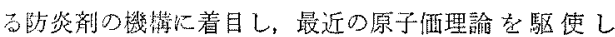

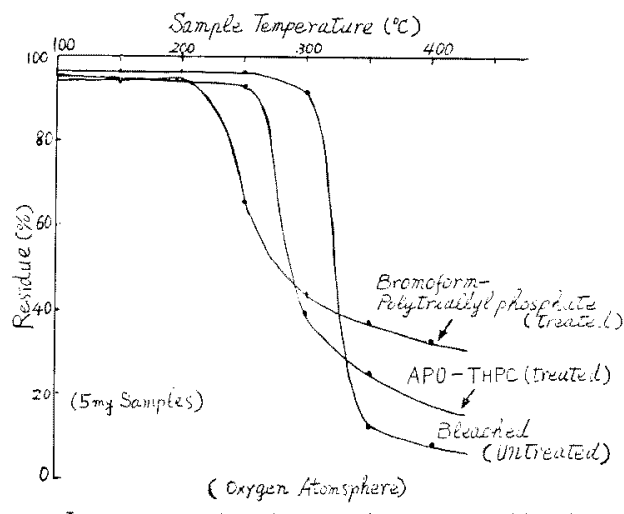

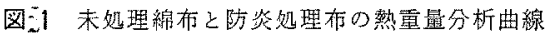


334

$\tau$, Lewis の胆之た霆子受客体 (electron acceptors)

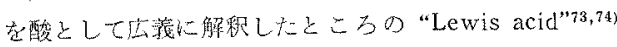
ふ，熱分解生成物としての形成されることが，防次剂の 一大条件でるるとしているつは，注目される説である。

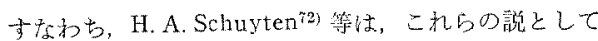
次のように述べている。

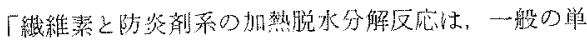

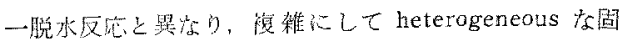

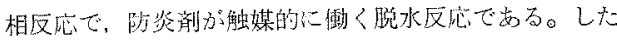

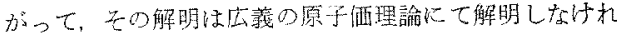
ば，とても明らがすることはでさな。すなわち，

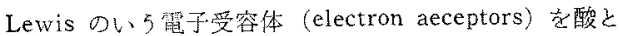
して解积したところの “Lewis acid”加，蓺分解物とし

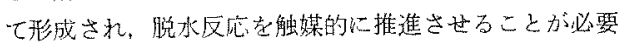

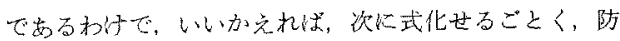
炎剂自身主たは防焱剂の分解生成物か，Lewis acid

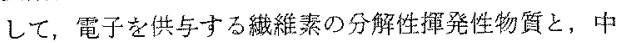
間的に結合して，不择発性物質を形成し，それ名触媒的 に水之残渣 (charred residue) に促進分解されると， 考觉られるおけであ。

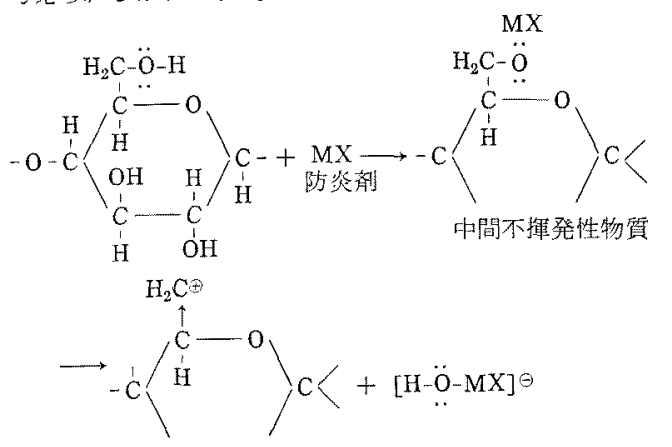<smiles>CC(C)C(C)OC(C)(C)C</smiles>

部分脱水グルロース残渣

䠉して

$[\mathrm{H}-\ddot{\mathrm{O}}-\mathrm{MX}] \ominus+\mathrm{H}^{\oplus} \longrightarrow \mathrm{HOH}+\mathrm{MX}$

そこに招いて，紷維素の防炎嘰作は次の上らに律する ことぶできる。

（1）防炎剂は，アルコールまたはグライコールの脱 水反沁洔して提示されたと同じよちなカルボニウム・ イオン穖作 ${ }^{75}$ 経て，防炎用とセルロースとの反応に上 る，セルロースの接触脱水分解をむたらさなければなら tsho

（2）防炎性を有する物筫は，せルロースの燃焼近辺
織維亡工業

の温度で，それ自身存在するか、亲たはと近辺の温度

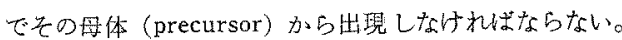

(3) 防㶤剂は $300 \sim 500^{\circ} \mathrm{C}$ て揮発末たは蒸発しては ならない。

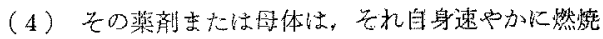
してはならない。

（5）防炎性存する物質は，七ルロ一スの然焼温度 で Lewis acid であるか，Lewis acidを生成する居の でなければならない。

これについては，同じニューオりンズの J. L. Drake $\mathrm{Jr}^{7}$.6) 方, 最近のAm. Dyestuff Reporter 誌に, 次の点 につき同じょ5に発表している。

「最近の理論の主なる点は，次の如くである。

（1）七ルロースの防炎に括ける主なる反応は，カル ボニウム・イオン機作に上って，防烦剂が螌媒として動 くことによる脱水反応である。

（2）防炎剤の螌媒的効果は，ガスの発火温度以下に 扣いて脱水を促進することにより，ガス発生の部合を変 化促進させるるとにある。

（3）防㭥触煤は, Lewis acid (electron acceptor)' または Lewis base (electron donor) で，旮就七儿 ロースの然滰温度近辺で存在するか，または防炎剤から。 発生しなければならない。」

また，趣きをか光た理諭として，J，L.Drake Jr. は最

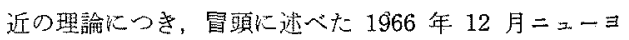
ークに执て開催されだ “Conference on Burns and Flame Retardant Fabrics" 厄拈いて, "Flame Retardants and their Application to Textiles" なる諈演 ${ }^{3}{ }^{3}$ および先はとの Am. Dyestuff Reptr，の報文泊)の中 で、次のよらな研究を紹介している。

「綿の加熱分解の結果の生成物については，与て広 筙な研笕がなされた。すなわち，ガス体，炭素数 1 て 個の自機化合物, Levoglucosan（䒜水のグルュースで, free のカーボニール基をもたない，熱や薬品比安定な 七ルロース真空菽留分）や，水を含む 18 種類の分解生 成物が鑑別された。

この綿の熱分解の分解過程之その生成物の再組識によ る結合圥解明するた好， “free radical mechanism” 理諭が仮定されてきた。J.C. Arthur Jr. な゙どによる最 近の研究77\}虫この “free radical mechanism” の理論を” 裏つけける役立った。Arthur 等の央験の結論は, 䄸せ ルロースの熱分解に上る free radieál ${ }^{18)}$ の発生は，

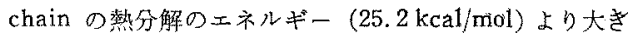
く，すでに報告された酸に上る脱水分解の土未ルギー (35〜40 kcal/mol) と注同じであることを分らせだ。 さらに, Arthur などは free radical mechanism は綿 
セルロースの分解に括いて营起され，七ルロースに aromatic group の上うなある種の基を付加することによ り, free radical の生成は減少すること艺提示してい る。 free radical 生成の滅少は, 七ル口一スの耐资性を 増大する。この基䃈的知識は，新しいしか子上り㑯れた 鼣の防炎加工の登展を導くのに役立つと思５。」

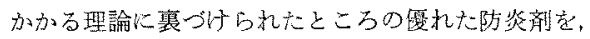
数多くの無機むるい方有機化合物の中から探し求めた り, 合成したりする場合の示唆として, 防炎用の具備条 件は，しからばいかなるるすのであるるか，といらことを 知名必要が出ると思う。气れらについては，同じくJ。 L. Drake Jr. が，1962 年ボストンに执いて開かれた “Textile Flammability Confererce”に拈いて詳細な講

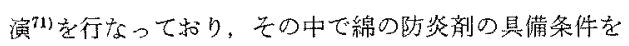
次の如く導き出しているので引用記载すると,

（1）リンと窑素を含有す苛化合物が，よい防炎性を 与点得ること。

（2）然堯生成物として Lewis acid が形成されるこ とが，綿の防炎に対して必要であること。

（3）綿に対して適切な防炎珄を与えるためには, 処 理に上って付着させる防炎剂の熱分解点が $275^{\circ} \mathrm{C}$ か

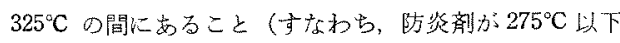
で分解する場合は綿が燃焼索開始する前火分解されてし 票万し，所炎剤が $325^{\circ} \mathrm{C}$ 以上で分解する埸合は Lewis acid ができる前に綿か燃焼してしまう)。

と述べて，また一般的によい耐久性のある越料用の防 炎剤としての其倩条件として, 非常に至難ではむるが,

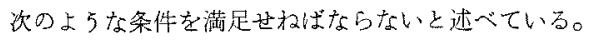

（1）水溶液の形で布に処理し5ること。

（2）一般の織物加工工場が有している設備・機械・ 装置で処理可能なこと。

（3）織物の性質をそこなわないこと。たとえば触感， 引裂強度, 引張強度など。

（4）洗䍜などル耐久性のある防资性が与えられるこ 之o

（5）粉末のようなものを布上に発生させないこと。 すなわち，不適切な処理が施されたとき，处理布をもえ な゙りすると，薬剤が粉になって飛び散る場合があるが， その上うな結果をるたらさないこと。

（6）岁る程度以上吸湿しないこと。すなわり布が湿

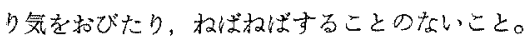

（7）着用する人火生理的害を与充ないこと。

（8）然焼したときに，外気と皮らとの間に織物の形 として残るような，文夫なるえさしを形成することが望 ましいこと。

（9）もちろん，綿に対して防资性とともに，防しん
性を与えること。

熶近また，同氏は，前述の1966 年ニニーヨークに和 ける Conference に扣いての講演扣よび報文 ${ }^{76}$ に, 形を゙ 变点て，「使用上渾足できる防炎剤の条件」として，乙 の主要点をたく双にらら，次の如く発表している。

（1）容易に加工し得ること。すなわら，一般的な加 工設䚚にて, 水溶液にて処理しらること。

（2）はなはだしい重量增加がなく，少ない付着量に て効力のあるこる。

(3) 洗濯・ドライクリーニングに耐えること。

(4) 通気性が保持されること。

(5) 生理的に無害でるること。

(6) 防じ兀性のあること。

（7）触感として，杮を堅くしないこと。

（8）強度低下を薏起しないこと。

（9）谪正なコストなること。

\section{5. 結䨐}

以上，赫維の防炎加工につき，その加工剂を中心とし た加工方法の概要，ならびに防炎理椧の歴史的展開と, 最近の理論の一端を述べたが，その研究と開発は置頭に 述べた如く，その高度の必要性に迫られ，今後ますます 発展していくるのと思われる。事実，現今に赫てて，在 料などの軽布に対して, 耐洗濯性のある防资加工剂は,

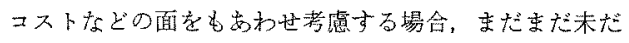
しの感があり，最近あらゆる重量の織物の防炎に有効な 上万に，空素に対するリンの比率の大きな防炎剤の研 究3,76) が進められているとのことであるし，また，ての 詳細は群びらかでないが、ニーオリンズに利いては、 特以軖布の加工に舆味のある新加工力法を，またまた開 発したとい5報告 ${ }^{99}$ あるような状況である。

また，当然問題となるべき合成緎維に対なる加工につ いては，それ自身難燃性の modified acrylics (アクリ ルおよび塩化ビニル共重合繊維）は別として、ポリアミ ド、ポリエステルなどの瀻維に関しては，最低 $50 \%$ 以 上の綿をたはレーヨンを混紡してあれば，本文に記載さ れたごとき，織維素䋘維の代表的防炎用は応用できる

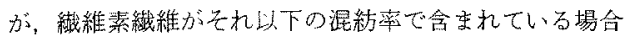

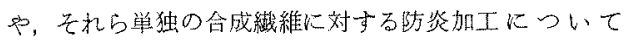

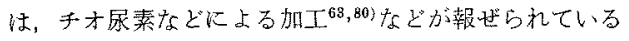
ので次の機会にご紹介したいと思う。

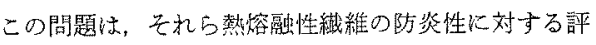
価試験方法の改良 ${ }^{811}$ ，確立も，まずなされねばならず， また広義の防炎性，才な方 Du Pon’tの“Nomex Nylon”82)のような，酎熱性合成瀻維の開発にまで問題 が，桩大研究されていくことが望まれるわけである。 


\section{文献}

60) E. Heuser ; "The Chemistry of Cellulose", p, 546, John Wily \&Sons, New York, 1944

61) W. G. Wolfgang ; "The Burning Characteristics of Fibers", in "Man-Made Textile Encyclopedia", edited by J. J. Press, Textile Book Publishers, Inc., New York, 1959

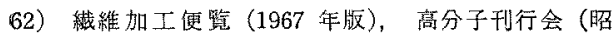
41); p. $4 \mathrm{I} 6$

63）同上, p. 125

64) H. F. Coward, G. W. Jones; U.S. Bur. Mines, Bull., 503 (1952)

65) M. Leatherman; “Weather Resistant Fireproofing Treatment for Cotton Fabrics", U. S. Dept. Agriculture, Circ. No. 466 (1938)

66) J. M. Charch; "Fundamental Studies of Chemical Retardants for the Fire-Resistant Treatment of Textiles", U, S. Q. M. C. Textile Series, Rept. 38 (1952)

67) S.Coppick, J.M.Church, R. W. Little ; Ind. Eng. Chem., 42, 415 (1950)

68) T. Miles; Textile Functional Finishes Laboratory Report No. 136, "Thermal Decomposition of Flame Retardant Treated Fabrics", Quartermaster Research and Development Command, Natick, Mass., (1954)

69) I. M. Gottlieb ; Tex. Res.J., 26, 156 (1956)

70) R.M. Perkins, G. L. Drake Jr., W.A. Reeves, J. of Applied Polymer Sci., 10, No. 7, p. 1041 $\sim 1066$ (1966)

71) J. L. Drake Jr.; "Research at Southern Utilization Research and Development Center", in "Textile Flammable Conference", (Oct. $2 \sim 3$,
1962), p. 30 32, published by National Fire Protection Association, Boston, Mass.

72) H. A. Schuyten, J. W. Weaver, J. D. Reid ; "Some Theoretical Aspects of the Flamproofing of Cellulose", in "Fire Retardant Paint", No. 9 the Advance in Chemistry Series, p. $7 \sim 20$, published by Am. Chem. Soc., Washigton, D.C. (1954)

73) W. F. Luder, S.Zuffani ; "The Electron Theory of Acids and Bases", John Wiley \& Sons, New York (1946)

74) R. B. Heslop, P. L. Robinson ; "Inorganic Ch. mistry", Elsevier Publishing Co. (1960) 一邦 訳; 斎藤訳「無機化学」，上，p. 234 (1963)

75）高分子実験学丵座 10 「重合と解重合反応」，p. 62 157，共立出版（昭 34）

76) G. L. Drake Jr. ; Am. Dyestuff Reptr., 56, No. 15, 560 564 (July 17, 1967)

77) J.C. Arthur Jr.; O. Hino;osa, Tex. Ses. J., 36,385 (1966)

78) free radical - S. Glasstone ; "Text-book of Physical Chemistry" p. 1063, Van Norstrand Co. Inc., New York (1940)

79) Am. Dyestuff Reptr., 56, No. 13, 446 (June 19, 1967)

80) J. d'Albignac; J. Soc. Dyers Col., 82, 339 345 (1966)

81) A. S. Endler, M. L. Hurmitz ; Am. Dyestuff Reptr. 56, No. 19, 694 (Sep. 11, 1967)

82）耐熱性ボリアミド瀻維一一兴田，高分子加工，16 No. 10,528 (1967 年 10 月)

(昭和 42 年 11 月 27 日受理) 